\title{
Assessment of the Influence of Oil Palm and Rubber Plantations in Tropical Peat Swamp Soils Using Microbial Diversity and Activity Analysis
}

\author{
Yuana Nurulita1,2, Eric M. Adetutu1 ${ }^{1}$, Krishna K. Kadali' ${ }^{1}$, Esmaeil Shahsavari' ${ }^{1}$, Delita Zul ${ }^{3}$, \\ Mohamed Taha',4, Andrew S. Ball ${ }^{1}$ \\ ${ }^{1}$ Centre for Environmental Sustainability and Remediation, School of Sciences, RMIT University, \\ Melbourne, Australia \\ ${ }^{2}$ Chemistry Department, Faculty of Mathematics and Natural Sciences, University of Riau, \\ Pekanbaru, Indonesia \\ ${ }^{3}$ Biology Department, Faculty of Mathematics and Natural Sciences, University of Riau, Pekanbaru, Indonesia \\ ${ }^{4}$ Department of Biochemistry, Faculty of Agriculture, Benha University, Toukh, Egypt \\ Email: andy.ball@rmit.edu.au
}

Received 11 February 2016; accepted 26 April 2016; published 29 April 2016

Copyright (C) 2016 by authors and Scientific Research Publishing Inc.

This work is licensed under the Creative Commons Attribution International License (CC BY).

http://creativecommons.org/licenses/by/4.0/

(c) (i) Open Access

\section{Abstract}

In this study, tropical peat swamp soils from Giam Siak Kecil-Bukit Batu Biosphere Reserve (GSKBB) in Indonesia was evaluated to assess the impact of oil palm and rubber plantations on this unique organic soil through comparisons with soils from a natural forest using a polyphasic approach (chemical and molecular microbial assays). Changes in the ammonium, nitrate and phosphate concentration were observed in soils converted to agricultural use. Soil enzyme activities in plantation soils showed reduced $\beta$-glucosidase, cellobiohydrolase and acid phosphatase activities (50\% - 55\% decrease). PCR-DGGE based analysis showed that the soil bacterial community from agricultural soils exhibited the lowest similarity amongst the different microbial groups (fungi and Archaea) evaluated (34\% similarity to the natural forest soil). Shannon Diversity index values showed that generally the conversion of tropical peatland natural forest to rubber plantation resulted in a greater impact on microbial diversity (ANOVA $p<0.05$ ). Overall, this study indicated substantial shifts in the soil microbial activity and diversity upon conversion of natural peatland forest to agriculture, with a greater change being observed under rubber plantation compared to oil palm plantation. These findings provided important data for future peatland management by relating changes in the soil microbial community and activities associated to agricultural practices carried out on peatland. 


\section{Keywords}

\section{Tropical Peat Swamp Soil, Microbial Community, Soil Enzyme, Oil Palm Plantation, Rubber Plantation}

\section{Introduction}

Indonesian peatlands are important natural resources with considerable environmental and economic value. This is because they are habitats for scarce fauna, provide important sources of water and are crucial for flood control. With 16.5 - 27 million hectares of peatland, Indonesia has the largest peat swamp area in Asia and the fourth largest in the world in terms of the global distribution of peat soils [1]. Generally, peat soils are composed of at least $65 \%$ organic matter and less than 35\% mineral content [1] [2] and their high organic matter contents are responsible for the acidic conditions, low nutrient and dissolved oxygen concentrations and slow rates of decomposition in this soils. The majority of the Indonesian peatlands in particular are under tidal influence with the fluctuating level of sea/river water disturbing the soil water table. Based on the geographic condition of peat formation, the sulfidic content of the peat is likely to be high. As a result of these factors, only limited areas of Indonesian peatland are thought to be suitable for agricultural practices [3].

The conversion of Indonesian peat swamp forests for agricultural use is becoming a major concern in terms of the sustainability of peatlands. Peatland deforestation, degradation and fires are estimated to have increased carbon dioxide emissions by $0.5 \mathrm{Pg} \mathrm{C}_{\text {year }}^{-1}$ [4] [5]. In addition, studies on the impact of agriculture confirm that methane emissions from paddy cultivations are significantly higher (33\%) than those from secondary forest [6]. Martikainen, Nykänen [7] found that the rates of mineralization of organic matter and soil microbial nitrous oxide production had also increased in the drier northern peatlands of Finland. Increasing decomposition processes also result in declining organic particle size, cramped pores and a reduction in water content [8]. This inevitably leads to adverse effects on their ecological function and the important environmental services they provide.

The Giam Siak Kecil-Bukit Batu (GSKBB) Biosphere Reverse in Indonesia represents a tropical peat swamp forest covering around 700,000 ha. This Biosphere Reserve is listed as a World Heritage Forest Sites [9] [10]. It contains a unique peat swamp forest in which peat depth can reach up to $20 \mathrm{~m}$ [11] [12]. This area consists of primary and secondary forest and peatland being used for agricultural purposes. Many human activities occur in the GSKBB and surrounding areas; this has resulted in significant ecosystem and ecological disturbance of the area. The activities include forest clearing, forest fires, illegal logging, industrial forestry replanting and agriculture (mainly for oil palm and rubber plantations). These activities can affect the environment and change microbial diversity and activity causing a significant alteration in soil microbial communities. As a World Heritage Forest site, it is important to know the impact of human practices especially oil palm and rubber plantations on this unique fragile ecosystem.

Changes in peatland-use such as the ones occurring in Indonesian peatlands can influence natural biogeochemical cycles, microbial function and diversity; these effects can be assessed through a number of physical, chemical and biological parameters. Microorganisms play fundamental roles in the biogeochemical cycling of many elements and in the formation and maintenance of soil structure, soil quality and fertility [13] [14]. Different soil management regimes have been shown to affect the structure and activities of soil microbial communities via changes in the quantity and quality of plant material that enter the soil [15]-[18]. The microbial diversity of peat swamp soil has previously been reported to change as a result of natural and anthropogenic disturbances [19].

Soil enzyme measurements are important as indicators of soil nutrient cycling and metabolic potential and can provide valuable information on the impact of land use on soil health and the sustainability of particular types of land management [20]-[22]. Enzyme activities, such as $\beta$-glucosidase, cellobiohydrolase, chitinase and acid phosphatase are involved in $\mathrm{C}, \mathrm{N}$ and $\mathrm{P}$ cycling and catalyze organic matter decomposition and nutrient mineralization. These key soil enzymes have been used extensively in soil research as their activities have been shown to be sensitive to land-use change [23]-[25]. The availability of soil nutrient to plants is important for ensuring agricultural sustainability. Therefore, changes in the activity and diversity of the soil microbial community will 
provide significant information relating to the sustainability of agricultural systems in the peat swamp area.

Currently, there is limited information available on the distribution and characteristics of tropical peatlands compared to boreal and temperate peatland and even less is known about the impact of land management practices [26]. For example, boreal and temperate peatlands have well documented reports of their microbial diversity and activity [27]-[29], differentiation of chemical and microbial diversity in ombrotrophic peat bog [30], organic matter transformation [31] and nutrient and carbon dynamics of drought gradations [31] [32]. It is important to note here that Indonesian peat swamp forest conversion to agricultural use is currently being carried out without due consideration to its future impact especially on the sustainability of this unique ecosystem. Therefore, this paper aims to investigate the impact of oil palm and rubber plantations through comparisons with soils from a natural forest using chemical and molecular microbial assays. The relationship between microbial activity and diversity in tropical peat swamp soils in response to peatland use for oil palm and rubber plantations was assessed.

\section{Materials and Methods}

\subsection{Study Sites and Soil Sampling}

The study sites were selected within the Giam Siak Kecil-Bukit Batu (GSKBB) Biosphere Reverse in SumateraIndonesia. It is located between $0^{\circ} 44^{\prime}-1^{\circ} 11^{\prime} \mathrm{N}$ and $0^{\circ} 11^{\prime}-102^{\circ} 10^{\prime} \mathrm{E}$ in two districts (Bengkalis and Siak) and one city (Dumai), in Riau Province [9]. These sites (natural forest (NF), oil palm (OPP) and rubber (RP) plantations) have peat thickness of around $1.7-5.5 \mathrm{~m}$ with a water table depth of $11-78 \mathrm{~cm}$ (Nurulita et al. 2015). Soil samples were collected in $9 \mathrm{~m}^{2}$ grids, using five sampling points (depth $10-15 \mathrm{~cm}$ ) within each grid (four in the corner and one in the middle of sampling area). The samples were bulked and transported to Australia for analyses. Further details regarding the sampling are described in Nurulita et al. (2015).

\subsection{Ion Concentrations}

Ammonium, nitrate, nitrite and phosphate were measured using a Dionex ICS-110 (Thermo Scientific)-ion chromatography (IC). Soil samples were serially diluted and the $10^{-3}$ soil diluent $(250 \mu \mathrm{l})$ was used for these elements determination. Analysis was carried out as per the manufacturer's protocols.

\subsection{Enzyme Activities}

Four soil enzymes, $\beta$-glucosidase and cellobiohydrolase (key enzymes in carbon cycle), chitinase (involved in both the $\mathrm{N}$ and $\mathrm{C}$ cycles), and acid phosphatase (involved in $\mathrm{P}$ cycle) were selected for study based on their importance in nutrient cycling in soils [33]. The activity of these enzymes were analysed using protocols described by Tabatabai and Bremner [34] involving the use of p-nitrophenol (p-NP) linked substrates with the colorimetric determination of pNP released by each enzyme when soil is incubated with a buffered substrate solution. Futher details regarding the enzyme activity analyses are decribed in Nurulita et al. [35]. Enzyme activity was expressed as nmol $p$-NP g $\cdot$ soil $^{-1} \cdot$ hour $^{-1}$.

\subsection{DNA Extraction}

DNA was extracted from soils (triplicate) using the method described by Steffan, Goksøyr [36] and Nurulita et al. [35] using glass beads and a miniBeatBeater (Biospec Product-USA) to release DNA from cells. The crude DNA extract was then cleaned with a GENECLEAN TURBO Clean up kit (MP Biomedicals LLC, USA) as per the manufacturer's instructions.

\subsection{PCR Amplification 16S rDNA}

PCR-DGGE was carried out on total bacterial, fungal and Archaeal communities to assess whether the changes in soil ion concentrations and enzyme activities led to shifting in the soil microbial communities [35]. The 16S rRNA genes of bacterial community were amplified using universal primers, the $314 \mathrm{~F}$ (5'-CGCCCGCCGCGC GCGGCGGGCGGGGCGGGG-3') with incorporation of a 40-bp GC clamp in the 5' primer and 907 R primers (5'-CCGTCAATTCCTTTRAGTTT-3') [37]. The bacterial community was amplified using RedTaq polymerase (Sigma) with the final $50 \mu \mathrm{l}$ reaction mixture for bacterial amplification containing $5 \mu \mathrm{l}$ of PCR buffer (Sigma), 
$5 \mu \mathrm{l}$ of RedTaq $\mathrm{MgCl}_{2}, 1 \mu \mathrm{l}$ of $10 \mathrm{mmol} \cdot \mathrm{l}^{-1} \mathrm{dNTP}, 2 \mu \mathrm{l}$ of $10 \mathrm{pmol}$ (each) of forward and reverse primers, $2.5 \mu \mathrm{l}$ of RedTaq polymerase $\left(5 \mathrm{U} \cdot \mu \mathrm{l}^{-1}\right), 0.25 \mu \mathrm{l}$ of bovine serum albumin [38] and $2 \mu \mathrm{l}$ of template DNA. The bacterial community PCR protocol was a touch-down thermal program which included an initial denaturation step of $95^{\circ} \mathrm{C}$ for 5 min followed by 15 cycles of $94^{\circ} \mathrm{C}$ for $30 \mathrm{~s}, 60^{\circ} \mathrm{C}$ for $30 \mathrm{~s}$ (with a $1^{\circ} \mathrm{C}$ decrease each cycle till $45^{\circ} \mathrm{C}$ ), $72^{\circ} \mathrm{C}$ for $1 \mathrm{~min}$, then by 20 cycles of $95^{\circ} \mathrm{C}$ for $45 \mathrm{~s}, 45^{\circ} \mathrm{C}$ for $45 \mathrm{~s}, 72^{\circ} \mathrm{C}$ for $2 \mathrm{~min}$, and a final extension of $72^{\circ} \mathrm{C}$ for $3 \mathrm{~min}$. The fungal community was amplified using a nested PCR, ITS1F primer (5'-CTTGGTCATTTAGAG GAAGTAA-3') and ITS4 primer (5'-TCCTCCGCTTATTGATATGC-3') were used for the first PCR, continued with ITS1F primer (5'-CGCCCGCCGCGCGCGGCGGGCGGGGCGGGGGCACGGGGGGCTTGGTCAT TTAGAGGAAGTAA-3') with incorporation of a 40-bp GC clamp in the 5' primer and ITS2 primer (5'-GCTG CGTTCTTCATCGATGC-3') [39]-[41]. The fungal community was amplified using GoTaq polymerase (Promega) with the final $50 \mu$ reaction mixture containing $10 \mu \mathrm{l}$ of $5 \times$ PCR buffer (Promega), $3 \mu \mathrm{lof} 25 \mathrm{mmol} \cdot \mathrm{l}^{-1}$ $\mathrm{MgCl}_{2}, 1 \mu \mathrm{l}$ of $10 \mathrm{mmol} \cdot \mathrm{l}^{-1} \mathrm{dNTP}, 2 \mu \mathrm{l}$ of $10 \mathrm{pmol}$ (each) of forward and reverse primers, $1 \mu \mathrm{l}$ of $1.25 \mathrm{U}$ of Taq polymerase $\left(5 \mathrm{U} \cdot \mu \mathrm{l}^{-1}\right), 0.25 \mu \mathrm{l}$ of bovine serum albumin and $2 \mu \mathrm{l}$ of template DNA. The fungal community PCR protocol also used a touch-down thermal program which included an initial denaturation step, $95^{\circ} \mathrm{C}$ for 5 min followed by 10 cycles of $94^{\circ} \mathrm{C}$ for $45 \mathrm{~s}, 68^{\circ} \mathrm{C}$ for $45 \mathrm{~s}$ (with a $1^{\circ} \mathrm{C}$ decrease each cycle till $58^{\circ} \mathrm{C}$ ), $72^{\circ} \mathrm{C}$ for $45 \mathrm{~s}$, then by 24 cycles of $94^{\circ} \mathrm{C}$ for $45 \mathrm{~s}, 58^{\circ} \mathrm{C}$ for $45 \mathrm{~s}$ and $72^{\circ} \mathrm{C}$ for $45 \mathrm{~s}$, and a final extension of $72^{\circ} \mathrm{C}$ for $10 \mathrm{~min}$. The Archaeal community was amplified by PCR using Arc931F primer (5'-AGGAATTGGCGGGGGAGCA-3') and Univ 1392R (5'-5'CGCCCGCCGCGCCCCGCGCCCGGCCCG CCGCCCCCGCCCCACGGGCGGTGT GTAC-3') with incorporation of a 40-bp GC clamp in the 5' primer [42]. The Archaeal community was amplified using MyTaq polymerase (Bioline) with the final $50 \mu \mathrm{l}$ reaction mixture for Archaeal amplification containing $10 \mu \mathrm{l}$ MyTaq buffer (Bioline), $2 \mu \mathrm{l}$ of $10 \mathrm{pmol}$ (each) of forward and reverse primers, $0.25 \mu \mathrm{l}$ of $1.25 \mathrm{U}$ of MyTaq polymerase $\left(5 \mathrm{U} \cdot \mu \mathrm{l}^{-1}\right), 0.25 \mu \mathrm{l}$ of bovine serum albumin and $2 \mu \mathrm{l}$ of template DNA. The Archaeal PCR protocol included a 2 min initial denaturation at $95^{\circ} \mathrm{C}, 26$ cycles of $94^{\circ} \mathrm{C}$ for $45 \mathrm{~s}, 43^{\circ} \mathrm{C}$ for $45 \mathrm{~s}, 72^{\circ} \mathrm{C}$ for $45 \mathrm{~s}$ and a final extension $\left(72^{\circ} \mathrm{C}, 7 \mathrm{~min}\right)$.

\subsection{Denaturing Gradient Gel Electrophoresis (DGGE)}

DGGE was performed with a D-Code System (BioRad) in accordance with the manufacturer's instructions. PCR products were loaded onto polyacrylamide gels (37.5:1, acrylamide/bisacrylamide) in $1.0 \times$ TAE runing buffer (40 mM Tris-HCl, $40 \mathrm{mM}$ acetic acid, $1 \mathrm{mM}$ EDTA) with a denaturing gradient (where 100\% denaturant contains $7 \mathrm{M}$ urea and $40 \%$ formamide). The gradients used were $50 \%-60 \%$ for bacteria, $57 \%$ - $63 \%$ for fungi and $45 \%$ - $60 \%$ for Archaea. The polyacrylamide gels were run for $18 \mathrm{~h}$ at $60^{\circ} \mathrm{C}$ and $60 \mathrm{~V}$, silver stained and scanned using an EPSON Expression 1600 V. 2.65 E. as described in Nurulita et al. [35].

The digitalized DGGE gels were analysed using UPGMA (unweighted pair-group method with mathematic average) method using a Phoretix 1D software (United Kingdom) [35]. This software represents the value of normalization the volume data derived from the DGGE gels for each phylotype (band) within each community and representation as a proportion of the total volume data for that community ( $p i)$. Italso eliminates the background and automatically detects peaks when noise levels and minimum peak thresholds are set. $p i$ values as the proportion of members that a particular species contribution to the total in the sample were usedto calculatethe Shannon Weaver index $\left(H^{\prime}=-\Sigma p i(\ln p i)\right.$ ). It was to determine the diversity within each microbial community sample [33] [40] [43]. Data were subjected to Anova using SPSS22 software and means value was separated using the least significant difference (LSD) test at 5\% level of significance, where the $\mathrm{F}$ value was significant. The standard error (SE) was used where required. Principal-component analysis (PCA) was used using SPSS 22 for DGGE gels and XLstat for correlation analysis.

\section{Results}

\subsection{Effect of Land Use on Soil C, N and P Concentration}

Analysis of the soil samples confirmed that substantial changes in soil $\mathrm{N}$ concentration occurred due to changing land practices (Table 1). Nitrate concentration in soils from both oil palm and rubber plantations were 2 - 5 times higher than the concentrations in the natural forest soil. Phosphate concentrations in the oil palm and rubber plantations soils were also differed significantly from one another (63.3 and $\left.72 \mathrm{mg} \cdot \mathrm{kg}^{-1}\right)(\mathrm{p}<0.05)$, but not to the forest soil sample. 
Table 1. $\mathrm{N}$ and $\mathrm{P}$ ion concentrations in tropical peat swamp soil samples under different land management practices.

\begin{tabular}{ccccc}
\hline \multirow{2}{*}{ Sample } & \multicolumn{3}{c}{${\mathrm{mg} \cdot \mathrm{kg}^{-1}}$} \\
\cline { 2 - 5 } & Ammonium & Nitrite & Nitrate & Phosphate \\
\hline NF & $*$ & $2.9 \pm 1.4$ & $138.9 \pm 2.1^{\mathrm{c}}$ & $63.3 \pm 2.2^{\mathrm{ab}}$ \\
OPP & $17.6 \pm 1.0^{\mathrm{b}}$ & $*$ & $273.6 \pm 0.6^{\mathrm{b}}$ & $61.0 \pm 1.3^{\mathrm{b}}$ \\
RP & $214.8 \pm 1.7^{\mathrm{a}}$ & $*$ & $363.2 \pm 1.3^{\mathrm{a}}$ & $72.0 \pm 1.5^{\mathrm{a}}$ \\
\hline
\end{tabular}

Notes: Data are reported as mean and standard error of mean for three replicate. NF: Natural forest; OPP: Oil palm plantation of 8 - 10 years; RP: Rubber plantation of 5 - 10 years. Note: Samples with the different letter ${ }^{\mathrm{a}}$, ${ }^{\text {, }}$, and ${ }^{\mathrm{c}}$ are significantly different (ANOVA p < 0.05 ). ${ }^{*}$ concentration was below the detection limit of the instrument.

\subsection{Effects of Land-Use on Soil Enzyme Activities}

Having observed significant differences in the availability of the readily soluble $\mathrm{N}$ in the soils, the activities of four soil enzymes in all tropical peat swamp soil samples were investigated (Figure 1). The ability of the soil microbial community to utilize carbohydrate substrates represented by $\beta$-glucosidase, chitinase, cellobiohydrolase and acid phosphatase activities was investigated. Agricultural practices resulted in changes in enzyme activities compared with the natural forest. A significant decrease $(\mathrm{p}<0.05)$ in $\beta$-glucosidase, cellobiohydrolase and acid phosphatase activities was observed in soils from both the rubber and oil palm plantations compared with the forest soil (13.3\% - 85\% decrease) but an increase in chitinase activity (6\%) in the RP soil was observed (Figure 1).

\subsection{Influence of Land-Use Change on the Soil Microbial Community}

Measurement of the changes in the diversity of microorganisms in peat swamp soil caused by agricultural practices showed that changes were substantial (Figure 2). The bacterial community showed the greatest changes amongst the different microbial groups evaluated with both oil palm and rubber plantation soils indicating only $34 \%$ similarity to the original soil. However, fungal and Archaeal communities from oil palm and rubber plantations also showed similar divergence (44\% and 52\% similarity for oil palm soil and $33 \%$ and $44 \%$ similarity for rubber plantation soil fungal and Archaeal communities respectively compared to NF soil).

Principal component analysis (PCA) confirmed the trend observed in the UPGMA dendrogram result (Figure 3). PCA of tropical peat swamp soil samples showed that there were two distinct bacterial community clusters associated with oil palm and rubber plantation practices compared with natural forest, along the second principal component axis $(\Delta)$. Furthermore, on the first principal component axis, communities from soil taken from oil palm plantations (fungi and Archaea) were in the same cluster as the natural forest soil sample communities (fungi and Archaea). However, communities from rubber plantation soil (fungi and Archaea) clustered individually confirming that rubber plantation management caused a greater shift in the diversity of fungal and Archaeal communities in the GSKBB peat swamp soil than observed in oil palm plantation soil.

In terms of the bacterial community, the diversity of both agricultural soils was assessed. The Shannon diversity index $\left(H^{\prime}\right)$ values were significantly decreased (9.9\% for OPP and $8.3 \%$ for RP) compared with the natural forest soil. With respect to fungal diversity, OPP soil was not significantly different from NF soil; in contrast Archaeal diversity in this soil showed a significant reduction (7.45\%). The RP soil showed a significant decrease in fungal diversity (7.73\%) but increased Archaeal diversity (6.47\%) compared to the NF soil (Table 2).

\subsection{Key Relationship between Land-Use Change and Measured Parameters}

PCA analysis of all data collected was carried out to quantify the relative contribution of agricultural land-use management to soil activities and diversity (Figure 4). The first and second principal components explain the substantial variation between these soil samples considering all measured parameters (F1 varied by $61.31 \%$ while F2 varied by 38.69\%). Higher nitrite and lower nitrate concentrations were associated with NF soil characteristics; concomitantly, ammonium and phosphate concentrations were the most relevant factors for RP characteristics. While NF and RP soils characteristics were dependent on all hydrolase enzymes, the properties of OPP soil were not related to any enzyme activity. Focusing on microbial diversity, each soil sample type depended on specific microbial group's (NF, OPP and RP were associated with H' bacteria, H' fungi and H' Archaea respectively). 


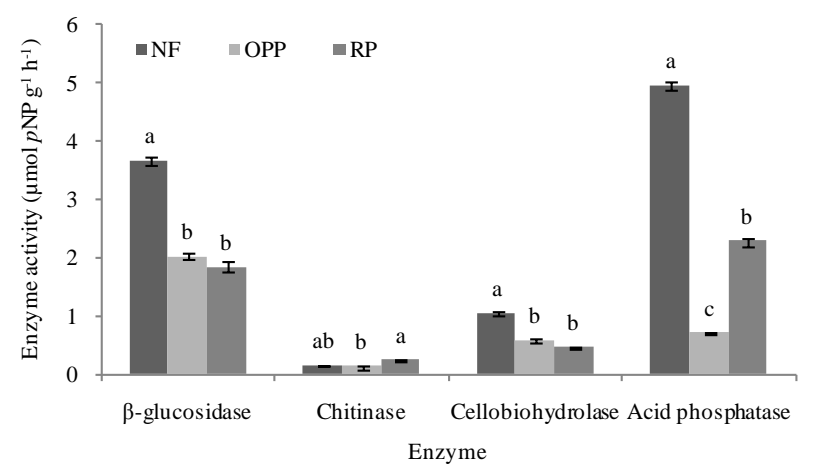

Figure 1. The activities of selected hydrolytic enzymes from the microbial community of tropical peat swamp soil $(\mathrm{n}=3)$ using $p$-nitrophenol $(p N P)$ linked substrates. NF: Natural forest, OPP: Oil palm plantation of 8 - 10 years old, RP: Rubber plantation of 5 - 10 years old. Note: bars topped by the same letter $\left({ }^{\mathrm{a}},{ }^{\mathrm{b}}\right.$, and $\left.{ }^{\mathrm{C}}\right)$ do not differ.
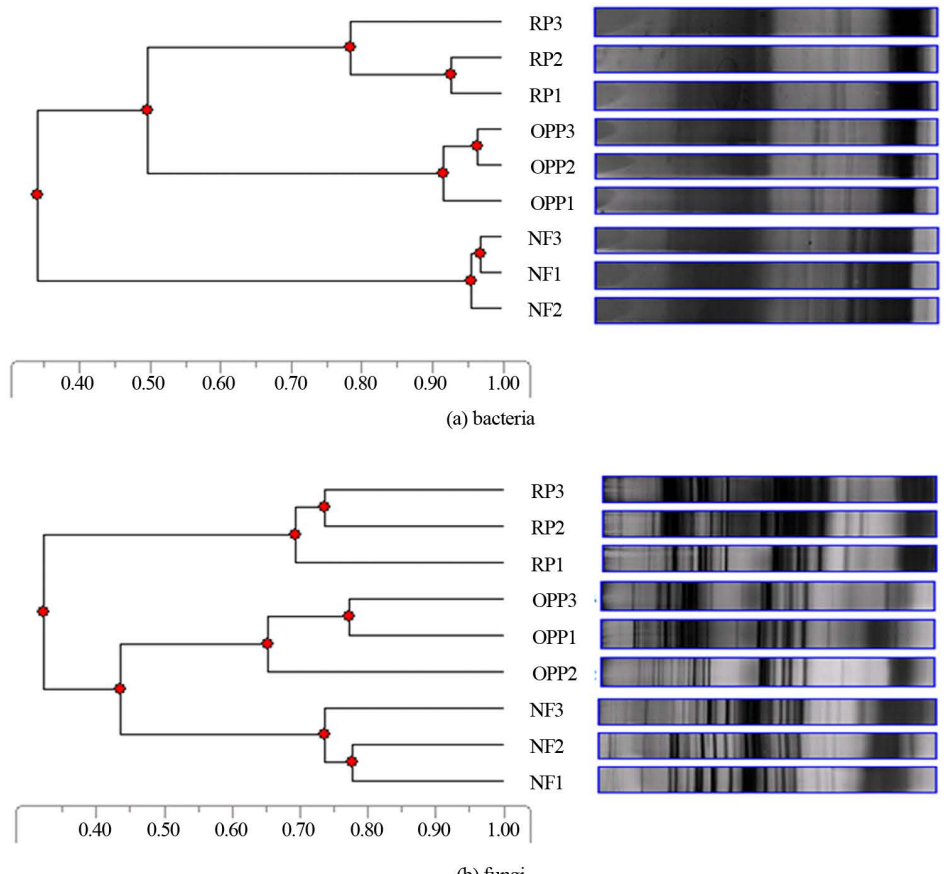

(b) fungi
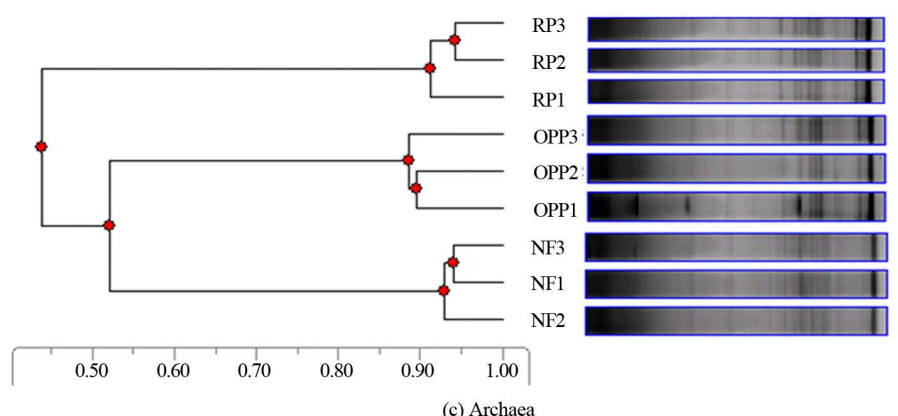

(c) Archaea

Figure 2. UPGMA dendrogram of microbial communities based on 165 rDNA DGGE profiles of tropical peat swamp soil samples generated with Phoretix software (Non-Linear Dynamics, Durham, USA). NF: Natural forest, OPP: Oil palm plantation with the age of oil palm plants 8 - 10 years and RP: Rubber plantation with the age of rubber plants 5 - 10 years, while 1, 2 and 3 refer to triplicate samples. 


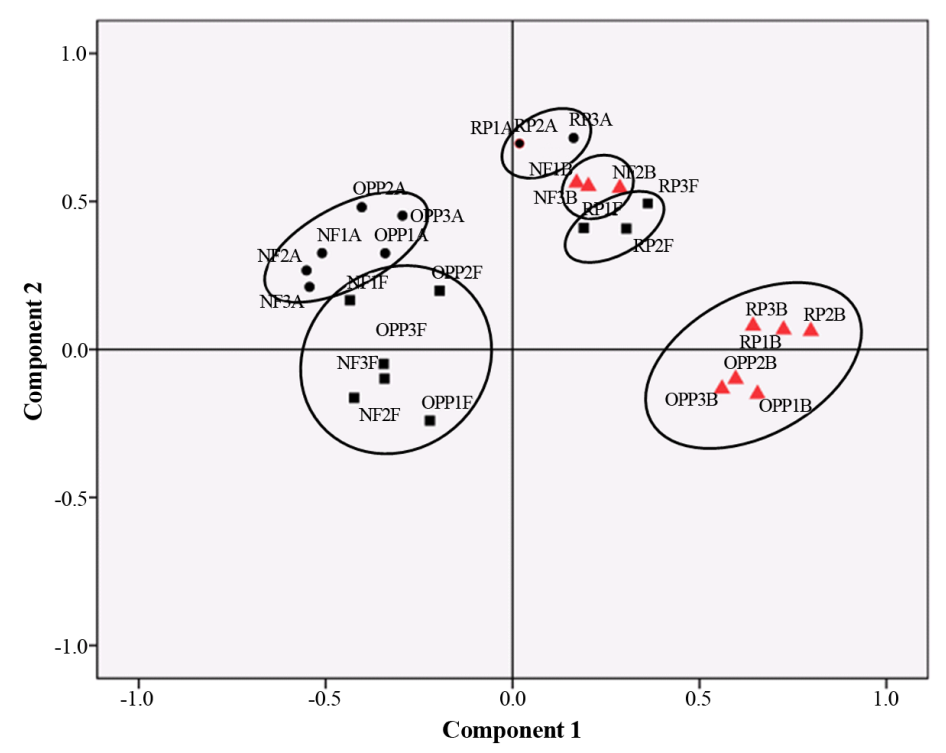

Figure 3. Principal component analysis (PCA) based on 16S rDNA and ITS DGGE profiles of tropical peat swamp soil samples generated with SPSS v21. NF: natural forest, OPP: Oil palm plantation with the age of oil palm plants 8 - 10 years and RP: Rubber plantation with the age of rubber plants 5 - 10 years, while 1,2 and 3 refer to sample replicates, $\mathrm{B} \boldsymbol{\Delta}$ : bacterial community; F $\mathbf{~ : ~ f u n g a l ~ c o m m u n i t y ~ a n d ~ A ~ \bullet ~ : ~ A r c h a e a l ~ c o m m u n i t y . ~}$

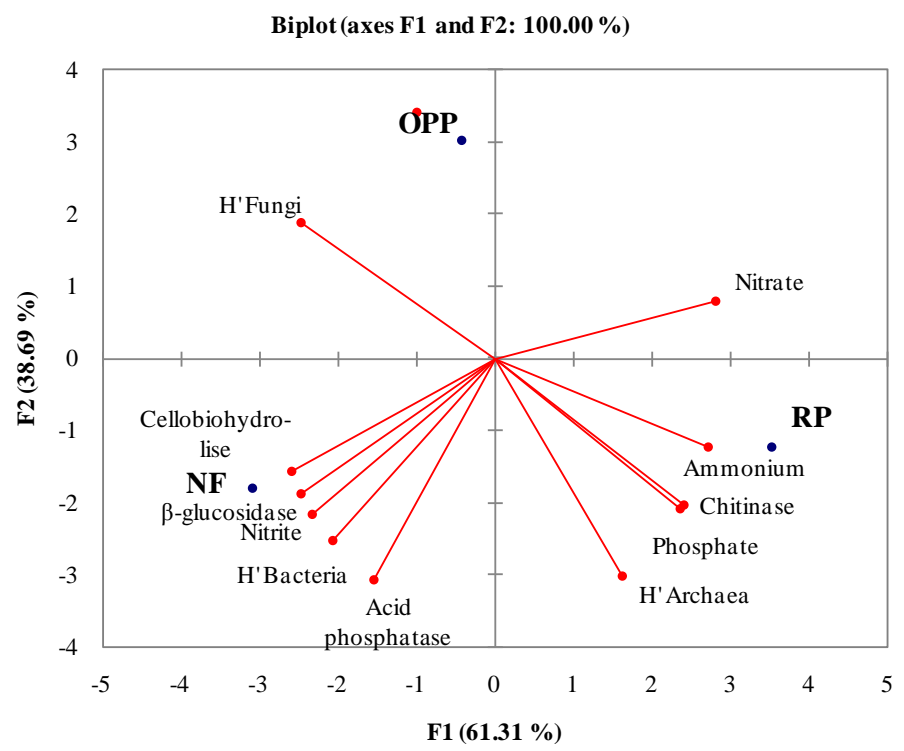

Figure 4. Principal Component Analysis (PCA) based on biological and physico-chemical characteristic data; abbreviation correspond to soil samples, NF: natural forest, OPP: Oil palm plantation with the age of oil palm plants 8 - 10 years and RP: Rubber plantation with the age of rubber plants 5 - 10 years. Total N: total nitrogen; Total C: Total Carbon. H' Bacteria, H’ Fungi and H’ Archaea are Shannon Diversity indexes of microbial diversities.

Conversion of peat swamp forest to agriculture resulted in changes in microbial functionality.

\section{Discussion}

\subsection{Effect of Land Use on Soil Ion Concentrations}

The low decomposition rate that is characteristic of peat soils represents a significant obstacle in terms of the 
Table 2. The Shannon Diversity index $(\mathrm{H})$ of microbial communities based on 16S rDNA and ITS DGGE profiles of tropical peat swamp soil samples from Indonesia.

\begin{tabular}{cccc}
\hline \multirow{2}{*}{ Sample } & & The Shannon diversity index $(\mathrm{H})$ & \\
\cline { 2 - 4 } & Bacteria & Fungi & Archaea \\
\hline NF & $2.52 \pm 0.03^{\mathrm{a}}$ & $2.88 \pm 0.07^{\mathrm{a}}$ & $2.55 \pm 0.02^{\mathrm{b}}$ \\
OPP & $2.27 \pm 0.03^{\mathrm{b}}$ & $2.92 \pm 0.06^{\mathrm{a}}$ & $2.36 \pm 0.14^{\mathrm{c}}$ \\
RP & $2.31 \pm 0.04^{\mathrm{b}}$ & $2.66 \pm 0.10^{\mathrm{b}}$ & $2.71 \pm 0.03^{\mathrm{a}}$ \\
\hline
\end{tabular}

NF: Natural forest, OPP: Oil palm plantation with the age of oil palm plants 8 - 10 years and RP: Rubber plantation with the age of rubber plants 5 10 years. Data are reported as means and standard errors of the means. Samples with the different letter ${ }^{\mathrm{a}}$, b, and ${ }^{\mathrm{C}}$ are significantly different (ANOVA $\mathrm{p}<0.05)$.

potential for the sustainability of agricultural practices in these soils. Plants require nutrients from soil microbial decomposition activities, but the fact that undisturbed peatlands represent significant carbon sinks suggests that decomposition activity is generally low in these soils. Zech et al. [44] described 2 phases of decomposition; firstly, the dominant process of mineralization of labile components and secondly, a slower mineralization due to the accumulation of refractory molecules. Nitrogen, one of the main plant growth nutrient is released during the decomposistion of organic matter. Nitrate concentrations in the agricultural soil samples (with no known records of fertilizer addition) were significantly higher (2 - 5 times) compared with the NF soil samples (Table 2, $\mathrm{p}<0.05)$. The increased levels of soil nitrate may be due to greater availability of nitrification substrates derived from local peat substances. Aerobic nitrification represents an important process in wetlands, although in peatland soils this process is far slower than seen in mineral soil due to limiting nitrifying microorganisms as a result of low low pH and oxygen availability. Nurulita et al. [45] reported that agricultural soils such as the ones used for this study exhibited reduced soil moisture content $(10 \%-20 \%)$ and a greater depth of water table (61 - 78 $\mathrm{cm}$ ). Low moisture content and drier soil can result in increased nitrification [7] [18], as observed in the more oxidized agricultural areas compared with natural forest peatland soils. With regards to the concentration of phosphate in agricultural soils, these were no significantly differences compared with the natural forest (average $\left.66.5 \mathrm{mg} \cdot \mathrm{kg}^{-1}\right)(\mathrm{p}<0.05)$.

\subsection{Effects of Land-Use on Soil Enzyme Activities}

Microorganisms catalyze biogeochemical shifts through changes in enzyme production [46]. In terms of enzyme activity, the activities in soils of peat swamp forest and those converted to agricultural land were found to vary considerably $\left(0.13-4.96 \mu \mathrm{mol} p\right.$ - $\left.\mathrm{NP} \mathrm{g}^{-1} \cdot \mathrm{h}^{-1}\right)$ (Figure 1). Comparing the data from the current study with other reported soil enzyme activities in other environments, the values reported here were lower in terms of $\beta$-glucosidase, but higher for acid phosphatase [47]. Generally, for mineral soil, enzyme activities in arable soil are higher than enzyme activities of forest soils; however, Kanokratana et al. [48] reported that metagenomicanalysis showed that for peat swamp forest soils, the number of genes encoding polysaccharide degrading enzymes was significantly higher than that found in sludge and farm soil. This study shows that apart from chitinase activities, conversion of peatland for agricultural use resulted in a reduction of $\beta$-glucosidase, cellobiohydrolase and acid phosphatase activities. The relatively high chitinase activity suggests a high metabolic demand for $\mathrm{N}$ released during chitin turnover [49]. Although not significantly different, the slightly higher acid phosphatase activity in NF and RP soils may have be driven by microbial $\mathrm{C}$ demand, considering the relatively large P-availability [50]. Currently there is comparatively limited information available on enzyme activities in peatlands and the impact of conversion to agricultural use. Bowles, Acosta-Martínez [15] stated that variation in enzyme activities could not be explained simply by soil type due to the narrow range of soil textures in peatland soil. The nutrient requirements of soil microbiota are dependent not only on the microbial community but also on the physical and chemical environment surrounding their habitats. Studies such as this are therefore important in generating baseline information on enzyme activities in converted tropical peatlands in addition to assessing the effects of peatland conversion.

\subsection{Influence of Land-Use Change on the Soil Microbial Community}

The changes in the soil microbial community in soils sampled from the different sites were assessed using a 
biomolecular approach. The results showed that bacterial community diversity was most affected by agricultural practices (only 30\% similarity compared with the microbial community present in the NF soil sample). Previously, it has been reported that there were greater shifts in the bacterial community in response to the conversion of tropical forest soils to oil palm plantations than logging activities [51] as well as long term fertilizer amendments [52]. The microbial diversity of the RP soil sample was significantly different (41\% different from fungal community and 50\% different from Archaeal community) and occurred in a different cluster in PCA analysis compared with NF (Figure 3). The microbial community of the OPP soil sample showed greater similarity (43\% for fungal community and 51\% Archaeal community) than the RP soil sample and was in the same cluster as the NF soil sample. The results suggest that in these tropical peat swamp soils, rubber plantation practices showed the greatest influences on microbial diversity compared to oil palm plantation practices.

Shannon Diversity index values confirmed that generally RP soil showed a greater impact on microbial diversity (8.3\% and 7.6\% decrease in bacterial and fungal diversity respectively, and a 5.9\% increase in Archaeal diversity) (Table 2). Schweitzer et al. [53] reported that plant gene diversity may alter soil microbial communities and their activities, which may have extended consequences for soil fertility. Patterns of soil microbial community are also dependent on soil moisture [54]. These factors could have played some role in the changes in the microbial diversity observed in this study.

Microbiological processes can be influenced directly by soil chemical properties through nutrients as well as carbon supply. Fungi as major decomposer [55] in acidic soils [56] have been suggested to play a dominant role in aerobic decomposition [29]. Interestingly, although the soil fungal and Archaeal diversity of the OPP soil sample showed similar diversity to that observed in the NF soil sample (Figures 2(b)-(c)), these soils did not exhibit the same potential to degrade carbon substrates. There was a substantial decrease in the enzyme activities determined in the OPP soil sample (13.3\% - 85.3\%) and in the levels of total $\mathrm{N}$ (i.e. an increased C:N ratio value) compared with the NF soil sample. In addition to low quality organic litter, reduced enzyme activities can be caused by an increase in the $\mathrm{N}$ ion concentration (ammonium and nitrate).

\subsection{Key Relationship between Land-Use Change and Measured Parameters}

Linking a large number of soil parameters to microbial community assessment may help in understanding the regulation of the activities of a microbial population. Such research can lead to the generation of ecological theories which may help predict peatland response to global change and anthropogenic disturbances. However, interpreting interactions between microbial diversity and function remain complex and challenging [57], yet it remains potentially a useful tool. Analysis of all the parameters in this study indicate that all peat swamp soils of GSKBB are clustered individually (Figure 4). A high C:N ratio is characteristic of OPP soils, suggesting that low decomposition rates may occur as a result of oil palm plantation practices on peat swamp soil. The palm monoculture system can result in considerable changes in the soil, such as topsoil damage, soil compaction and erosion [58] [59]. These changes sometimes correspond with diversity reduction, especially for decomposer species [60] [61]. High nitrite and low nitrate concentrations are associated with peat swamp natural forest soil (NF) (Pearson correlation coefficients -0.918, data not shown). Nurulita et al. (2015) found that agricultural practices on the GSKBB peat swamp soil resulted in a significant reduction in the moisture content of peat swamp soils. Decreasing soil moisture content can potentially result in increased nitrate loading if floodwaters quickly recede within a wetland [18].

The peat swamp natural forest soil is characterized by comparatively high enzyme activities with the exception of chitinase. Although fungi are suggested to play a major role in decomposition in natural forest peat soils [29] [55] [56], it appears not to be the case in this study. The composite PCA figure reveals that the peat swamp natural forest in the GSKBB biosphere reserve shows high correlation between bacterial diversity and enzyme activities ( $\beta$-glucosidase, cellobiohydrolase and acid phosphatase) with Pearson correlation coefficients ranging from 0.948-0.972 (data not shown). Bacterial abundance using conventional and molecular microbial methods have been reported in some studies to show a strong positive correlation with enzyme activities and also organic matter content [22]. However, Torsvik and Øvreås [62] state that although the relationship between microbial diversity and their function in soil is largely unknown, biodiversity is assumed to influence ecosystem stability, productivity and resilience towards stress and disturbance. Typically, soils show considerably functional redundancy [63] and it may yet be the case in some of the samples analysed in this study, although functional redundancy in microbial communities present in samples used for this study is not specifically investigated. 
In conclusion, the polyphasic approach used in this study involving soil chemical analysis and soil enzyme activities integrated with molecular microbial tools allowed us to assess the impact of oil palm and rubber plantations on the soil microbial community. This study indicated substantial shifts in soil microbial activity and diversity upon conversion of natural peatland forest to agricultural use. However, each soil exhibited a unique range of characteristics. These findings were important in generating baseline data on the effects of peatland conversion to agricultural use and in the development of peatland management strategies by providing information relating to the resilience of the soil microbial community and how tropical peat swamp ecosystems respond to agricultural practices.

\section{Acknowledgements}

This work was supported by Directorate General of Higher Education (DGHE)—Ministry of Research, Technology and Higher Education of Indonesia [No. 163/E4.4/K/2012].

\section{References}

[1] Sorensen, K.W. (1993) Indonesian Peat Swamp Forests and Their Role as a Carbon Sink. Chemosphere, 27, 10651082. http://dx.doi.org/10.1016/0045-6535(93)90068-G

[2] Andriesse, J. (1988) Nature and Management of Tropical Peat Soils. Food and Agriculture Organization (FAO) of United Nations, Rome.

[3] Agus, F. and Subiksa, I. (2008) Lahan Gambut: Potensi untuk Pertanian dan Aspek Lingkungan. Balai Penelitian Tanah dan World Agroforesty Centre (ICRAF), Bogor.

[4] van der Werf, G.R., Morton, D.C., De Fries, R.S., Olivier, J.G., Kasibhatla, P.S., Jackson, R.B., Collatz, G.J. and Randerson, J. (2009) $\mathrm{CO}_{2}$ Emissions from Forest Loss. Nature Geoscience, 2, 737-738.

http://dx.doi.org/10.1038/ngeo671

[5] van der Werf, G., Randerson, J.T., Giglio, L., Collatz, G., Mu, M., Kasibhatla, P.S., Morton, D.C., DeFries, R., Jin, Y.V. and Leeuwen, T.V. (2010) Global Fire Emissions and the Contribution of Deforestation, Savanna, Forest, Agricultural, and Peat Fires (1997-2009). Atmospheric Chemistry and Physics, 10, 11707-11735. http://dx.doi.org/10.5194/acp-10-11707-2010

[6] Hadi, A., Haridi, M., Inubushi, K., Purnomo, E., Razie, F. and Tsuruta, H. (2001) Effects of Land-Use Change in Tropical Peat Soil on the Microbial Population and Emission of Greenhouse Gases. Microbes and Environments, 16, 79-86. http://dx.doi.org/10.1264/jsme2.2001.79

[7] Martikainen, P.J., Nykänen, H., Crill, P. and Silvola, J. (1993) Effect of a Lowered Water Table on Nitrous Oxide Fluxes from Northern Peatlands. Nature, 366, 51-53. http://dx.doi.org/10.1038/366051a0

[8] Huat, B.B., Kazemian, S., Prasad, A. and Barghchi, M. (2011) State of an Art Review of Peat: General Perspective. International Journal of Physical Sciences, 6, 1988-1996.

[9] Gunawan, H., Kobayashi, S., Mizuno, K. and Kono, Y. (2012) Peat Swamp Forest Types and Their Regeneration in Giam Siak Kecil-Bukit Batu Bioshere Reserve, Riau, East Sumatra, Indonesia. Mires and Peat, 10, 1-17.

[10] Persic, A. and Ocloo, M. (2011) Biosphere Reserves, World Heritage Sites and People: Enhancing Synergies for Sustainable Forests, in Adapting to Change-The State of Conservation of World Heritage Forests in 2011. In: Patry, M., Horn, R. and Haraguchi, S., Eds., World Heritage Center-United Nations Educational, Scientific and Cultural Organization (UNESCO), Paris, 68-72.

[11] Sukara, E. and Purwanto, Y. (2009) Biosphere Reserve: The Management of Conservation Areas for Sustainable Economic Development. The 3rd Humanosphere Science School: Scientific Exploration and Sustainable Management of Peat and Land Resorces in Giam Siak Kecil-Bukit Batu Biosphere Reserve Riau, Pekanbaru, 4-5 August 2009, 1-20.

[12] Sutapa, I. (2009) Water Management System in Peat Swamp Region. The 3rd Humanosphere Science School: Scientific Exploration and Sustainable Management of Peat and Land Resorces in Giam Siak Kecil-Bukit Batu Biosphere Reserve Riau, Pekanbaru, 4-5 August 2009, 153-163.

[13] Arias, M.E., González-Pérez, J.A., González-Vila, F.J. and Ball, A.S. (2005) Soil Health—A New Challenge for Microbiologists and Chemists. International Microbiology, 8, 13-21.

[14] Wagg, C., Bender, S.F., Widmer, F. and van der Heijden, M.G. (2014) Soil Biodiversity and Soil Community Composition Determine Ecosystem Multifunctionality. Proceedings of the National Academy of Sciences of the United States of America, 111, 5266-5270. http://dx.doi.org/10.1073/pnas.1320054111

[15] Bowles, T.M., Acosta-Martínez, V., Calderón, F. and Jackson, L.E. (2014) Soil Enzyme Activities, Microbial Communities, and Carbon and Nitrogen Availability in Organic Agroecosystems across an Intensively-Managed Agricul- 
tural Landscape. Soil Biology and Biochemistry, 68, 252-262. http://dx.doi.org/10.1016/j.soilbio.2013.10.004

[16] Brouns, K., Verhoeven, J.T. and Hefting, M.M. (2014) The Effects of Salinization on Aerobic and Anaerobic Decomposition and Mineralization in Peat Meadows: The Roles of Peat Type and Land Use. Journal of Environmental Management, 143, 44-53. http://dx.doi.org/10.1016/i.jenvman.2014.04.009

[17] Mishra, S., Lee, W., Hooijer, A., Reuben, S., Sudiana, I., Idris, A. and Swarup, S. (2013) Microbial and Metabolic Profiling Reveal Strong Influence of Water Table and Land-Use Patterns on Classification of Degraded Tropical Peatlands. Biogeosciences Discussions, 10, 14009-14042. http://dx.doi.org/10.5194/bgd-10-14009-2013

[18] Peralta, A.L., Ludmer, S. and Kent, A.D. (2013) Hydrologic History Influences Microbial Community Composition and Nitrogen Cycling under Experimental Drying/Wetting Treatments. Soil Biology and Biochemistry, 66, 29-37. http://dx.doi.org/10.1016/j.soilbio.2013.06.019

[19] Andersen, R., Chapman, S. and Artz, R. (2013) Microbial Communities in Natural and Disturbed Peatlands: A Review. Soil Biology and Biochemistry, 57, 979-994. http://dx.doi.org/10.1016/j.soilbio.2012.10.003

[20] Nannipieri, P., Giagnoni, L., Renella, G., Puglisi, E., Ceccanti, B., Masciandaro, G., Fornasier, F., Moscatelli, M. and Marinari, S. (2012) Soil Enzymology: Classical and Molecular Approaches. Biology and Fertility of Soils, 48, 743-762. http://dx.doi.org/10.1007/s00374-012-0723-0

[21] Schloter, M., Dilly, O. and Munch, J. (2003) Indicators for Evaluating Soil Quality. Agriculture, Ecosystems \& Environment, 98, 255-262. http://dx.doi.org/10.1016/S0167-8809(03)00085-9

[22] Taylor, J., Wilson, B., Mills, M. and Burns, R. (2002) Comparison of Microbial Numbers and Enzymatic Activities in Surface Soils and Subsoils Using Various Techniques. Soil Biology and Biochemistry, 34, 387-401. http://dx.doi.org/10.1016/S0038-0717(01)00199-7

[23] Chen, R., Senbayram, M., Blagodatsky, S., Myachina, O., Dittert, K., Lin, X., Blagodatskaya, E. and Kuzyakov, Y. (2014) Soil C and N Availability Determine the Priming Effect: Microbial N Mining and Stoichiometric Decomposition Theories. Global Change Biology, 20, 2356-2367. http://dx.doi.org/10.1111/gcb.12475

[24] Shi, W. (2011) Agricultural and Ecological Significance of Soil Enzymes: Soil Carbon Sequestration and Nutrient Cycling. In: Shukla, G. and Varma, A., Eds., Soil Enzymology, Springer, Berlin, 43-60.

[25] Tischer, A., Blagodatskaya, E. and Hamer, U. (2014) Extracellular Enzyme Activities in a Tropical Mountain Rainforest Region of Southern Ecuador Affected by Low Soil P Status and Land-Use Change. Applied Soil Ecology, 74, 1-11. http://dx.doi.org/10.1016/j.apsoil.2013.09.007

[26] Zinck, J. (2011) Tropical and Subtropical Peats: An Overview. In: Zinck, J. and Huber, O., Eds., Peatlands of the Western Guayana Highlands, Venezuela, Springer, Berlin, 5-28. http://dx.doi.org/10.1007/978-3-642-20138-7_2

[27] Jackson, C.R., Foreman, C.M. and Sinsabaugh, R.L. (1995) Microbial Enzyme Activities as Indicators of Organic Matter Processing Rates in a Lake Erie Coastal Wetland. Freshwater Biology, 34, 329-342. http://dx.doi.org/10.1111/j.1365-2427.1995.tb00892.x

[28] Jackson, C.R. and Vallaire, S.C. (2007) Microbial Activity and Decomposition of Fine Particulate Organic Matter in a Louisiana Cypress Swamp. Journal of the North American Benthological Society, 26, 743-753.

http://dx.doi.org/10.1899/07-020R1.1

[29] Williams, R.T. and Crawford, R.L. (1983) Microbial Diversity of Minnesota Peatlands. Microbial Ecology, 9, $201-214$. http://dx.doi.org/10.1007/BF02097737

[30] Puglisi, E., Zaccone, C., Cappa, F., Cocconcelli, P.S., Shotyk, W., Trevisan, M. and Miano, T.M. (2014) Changes in Bacterial and Archaeal Community Assemblages along an Ombrotrophic Peat Bog Profile. Biology and Fertility of Soils, 50, 815-826. http://dx.doi.org/10.1007/s00374-014-0902-2

[31] Tfaily, M.M., Cooper, W.T., Kostka, J.E., Chanton, P.R., Schadt, C.W., Hanson, P.J., Iversen, C.M. and Chanton, J.P. (2014) Organic Matter Transformation in the Peat Column at Marcell Experimental Forest: Humification and Vertical Stratification. Journal of Geophysical Research: Biogeosciences, 119, 661-675. http://dx.doi.org/10.1002/2013jg002492

[32] Mettrop, I.S., Cusell, C., Kooijman, A.M. and Lamers, L.P. (2014) Nutrient and Carbon Dynamics in Peat from Rich Fens and Sphagnum Fens during Different Gradations of Drought. Soil Biology and Biochemistry, 68, 317-328. http://dx.doi.org/10.1016/j.soilbio.2013.10.023

[33] Girvan, M.S., Bullimore, J., Pretty, J.N., Osborn, A.M. and Ball, A.S. (2003) Soil Type Is the Primary Determinant of the Composition of the Total and Active Bacterial Communities in Arable Soils. Applied and Environmental Microbiology, 69, 1800-1809. http://dx.doi.org/10.1128/AEM.69.3.1800-1809.2003

[34] Tabatabai, M. and Bremner, J. (1969) Use of p-Nitrophenyl Phosphate for Assay of Soil Phosphatase Activity. Soil Biology and Biochemistry, 1, 301-307. http://dx.doi.org/10.1016/0038-0717(69)90012-1

[35] Nurulita, Y., Adetutu, E.M., Gunawan, H., Zul, D. and Ball, A.S. (2016) Restoration of Tropical Peat Soils: The Ap- 
plication of Soil Microbiology for Monitoring the Success of the Restoration Process. Agriculture, Ecosystems \& Environment, 216, 293-303. http://dx.doi.org/10.1016/j.agee.2015.09.031

[36] Steffan, R.J., Goksøyr, J., Bej, A. and Atlas, R. (1988) Recovery of DNA from Soils and Sediments. Applied and Environmental Microbiology, 54, 2908-2915.

[37] Zhu, L., Xu, H., Zhang, Y., Fu, G., Wu, P.Q. and Li, Y. (2014) BOX-PCR and PCR-DGGE Analysis for Bacterial Diversity of a Naturally Fermented Functional Food (Enzyme $\left.{ }^{\circledR}\right)$. Food Bioscience, 5, 115-122.

http://dx.doi.org/10.1016/j.fbio.2013.12.003

[38] Kreader, C.A. (1996) Relief of Amplification Inhibition in PCR with Bovine Serum Albumin or T4 Gene 32 Protein. Applied and Environmental Microbiology, 62, 1102-1106.

[39] Gardes, M. and Bruns, T.D. (1993) ITS Primers with Enhanced Specificity for Basidiomycetes-Application to the Identification of Mycorrhizae and Rusts. Molecular Ecology, 2, 113-118. http://dx.doi.org/10.1111/j.1365-294X.1993.tb00005.X

[40] Muyzer, G., De Waal, E.C. and Uitterlinden, A.G. (1993) Profiling of Complex Microbial Populations by Denaturing Gradient Gel Electrophoresis Analysis of Polymerase Chain Reaction-Amplified Genes Coding for 16S rRNA. Applied and Environmental Microbiology, 59, 695-700.

[41] White, T.J., Bruns, T., Lee, S. and Taylor, J. (1990) Amplification and Direct Sequencing of Fungal Ribosomal RNA Genes for Phylogenetics. Innis, M.A., Gelfand, D.H., Sninsky, J.J. and White, T.J., Eds., PCR Protocols: A Guide to Methods and Applications, Academic Press, Cambridge, MA, 315-322. http://dx.doi.org/10.1016/b978-0-12-372180-8.50042-1

[42] Jackson, C.R., Langner, H.W., Donaho-Christiansen, J., Inskeep, W.P. and McDermott, T.R. (2001) Molecular Analysis of Microbial Community Structure in an Arsenite-Oxidizing Acidic Thermal Spring. Environmental Microbiology, 3, 532-542. http://dx.doi.org/10.1046/j.1462-2920.2001.00221.x

[43] Shannon, C.E. and Weaver, W. (1949) The Mathematical Theory of Communication. University of Illinois Press, Champaign.

[44] Zech, W., Senesi, N., Guggenberger, G., Kaiser, K., Lehmann, J., Miano, T.M., Miltner, A. and Schroth, G. (1997) Factors Controlling Humification and Mineralization of Soil Organic Matter in the Tropics. Geoderma, 79, 117-161. http://dx.doi.org/10.1016/S0016-7061(97)00040-2

[45] Nurulita, Y., Adetutu, E.M., Kadali, K.K., Zul, D., Mansur, A.A. and Ball, A.S. (2015) The Assessment of the Impact of Oil Palm and Rubber Plantation on the Biotic and Abiotic Properties of Tropical Peat Swamp Soil in Indonesia. International Journal of Agricultural Sustainability, 13, 150-166. http://dx.doi.org/10.1080/14735903.2014.986321

[46] Zak, D.R., Blackwood, C.B. and Waldrop, M.P. (2006) A Molecular Dawn for Biogeochemistry. Trends in Ecology \& Evolution, 21, 288-295. http://dx.doi.org/10.1016/j.tree.2006.04.003

[47] Jackson, C.R., Liew, K.C. and Yule, C.M. (2009) Structural and Functional Changes with Depth in Microbial Communities in a Tropical Malaysian Peat Swamp Forest. Microbial Ecology, 57, 402-412. http://dx.doi.org/10.1007/s00248-008-9409-4

[48] Kanokratana, P., Uengwetwanit, T., Rattanachomsri, U., Bunterngsook, B., Nimchua, T., Tangphatsornruang, S., Plengvidhya, V., Champreda, V. and Eurwilaichitr, L. (2011) Insights into the Phylogeny and Metabolic Potential of a Primary Tropical Peat Swamp Forest Microbial Community by Metagenomic Analysis. Microbial Ecology, 61, 518-528. http://dx.doi.org/10.1007/s00248-010-9766-7

[49] Sinsabaugh, R., Antibus, R., Linkins, A., McClaugherty, C., Rayburn, L., Repert, D. and Weiland, T. (1993) Wood Decomposition: Nitrogen and Phosphorus Dynamics in Relation to Extracellular Enzyme Activity. Ecology, 74, 1586-1593. http://dx.doi.org/10.2307/1940086

[50] Stone, M., DeForest, J. and Plante, A. (2014) Changes in Extracellular Enzyme Activity and Microbial Community Structure with Soil Depth at the Luquillo Critical Zone Observatory. Soil Biology and Biochemistry, 75, $237-247$. http://dx.doi.org/10.1016/j.soilbio.2014.04.017

[51] Lee-Cruz, L., Edwards, D.P., Tripathi, B.M. and Adams, J.M. (2013) Impact of Logging and Forest Conversion to Oil Palm Plantations on Soil Bacterial Communities in Borneo. Applied and Environmental Microbiology, 79, $7290-7297$. http://dx.doi.org/10.1128/AEM.02541-13

[52] Marschner, P., Kandeler, E. and Marschner, B. (2003) Structure and Function of the Soil Microbial Community in a Long-Term Fertilizer Experiment. Soil Biology and Biochemistry, 35, 453-461. http://dx.doi.org/10.1016/S0038-0717(02)00297-3

[53] Schweitzer, J.A., Fischer, D.G., Rehill, B.J., Wooley, S.C., Woolbright, S.A., Lindroth, R.L., Whitham, T.G., Zak, D.R. and Hart, S.C. (2011) Forest Gene Diversity Is Correlated with the Composition and Function of Soil Microbial Communities. Population Ecology, 53, 35-46. http://dx.doi.org/10.1007/s10144-010-0252-3

[54] Ng, E.-L., Patti, A., Rose, M., Schefe, C., Smernik, R. and Cavagnaro, T. (2014) Do Organic Inputs Alter Resistance 
and Resilience of Soil Microbial Community to Drying? Soil Biology and Biochemistry, 81, 58-66.

[55] Orgiazzi, A., Lumini, E., Nilsson, R.H., Girlanda, M., Vizzini, A., Bonfante, P. and Bianciotto, V. (2012) Unravelling Soil Fungal Communities from Different Mediterranean Land-Use Backgrounds. PLoS ONE, 7, e34847. http://dx.doi.org/10.1371/journal.pone.0034847

[56] Thormann, M.N. (2006) The Role of Fungi in Boreal Peatlands. In: Wieder, R.K. and Vitt, D.H., Eds., Boreal Peatland Ecosystems, Springer, Berlin, 101-123. http://dx.doi.org/10.1007/978-3-540-31913-9_6

[57] O’Donnell, A.G., Seasman, M., Macrae, A., Waite, I. and Davies, J.T. (2001) Plants and Fertilisers as Drivers of Change in Microbial Community Structure and Function in Soils. Plant and Soil, 232, 135-145. http://dx.doi.org/10.1023/A:1010394221729

[58] Foster, W.A., Snaddon, J.L., Turner, E.C., Fayle, T.M., Cockerill, T.D., Ellwood, M.F., Broad, G.R., Chung, A.Y., Eggleton, P. and Khen, C.V. (2011) Establishing the Evidence Base for Maintaining Biodiversity and Ecosystem Function in the Oil Palm Landscapes of South East Asia. Philosophical Transactions of the Royal Society B: Biological Sciences, 366, 3277-3291. http://dx.doi.org/10.1098/rstb.2011.0041

[59] Yahya, Z., Husin, A., Talib, J., Othman, J., Ahmed, O.H. and Jalloh, M.B. (2010) Soil Compaction and Oil Palm (Elaeis guineensis) Yield in a Clay Textured Soil. American Journal of Agricultural and Biological Sciences, 5, 15-19. http://dx.doi.org/10.3844/ajabssp.2010.15.19

[60] Fayle, T.M., Turner, E.C., Snaddon, J.L., Chey, V.K., Chung, A.Y., Eggleton, P. and Foster, W.A. (2010) Oil Palm Expansion into Rain Forest Greatly Reduces ant Biodiversity in Canopy, Epiphytes and Leaf-Litter. Basic and Applied Ecology, 11, 337-345. http://dx.doi.org/10.1016/j.baae.2009.12.009

[61] Hassall, M., Jones, D.T., Taiti, S., Latipi, Z., Sutton, S.L. and Mohammed, M. (2006) Biodiversity and Abundance of Terrestrial Isopods along a Gradient of Disturbance in Sabah, East Malaysia. European Journal of Soil Biology, 42, S197-S207. http://dx.doi.org/10.1016/j.ejsobi.2006.07.002

[62] Torsvik, V. and Øvreås, L. (2002) Microbial Diversity and Function in Soil: From Genes to Ecosystems. Current Opinion in Microbiology, 5, 240-245. http://dx.doi.org/10.1016/S1369-5274(02)00324-7

[63] Nannipieri, P., Ascher, J., Ceccherini, M., Landi, L., Pietramellara, G. and Renella, G. (2003) Microbial Diversity and Soil Functions. European Journal of Soil Science, 54, 655-670. http://dx.doi.org/10.1046/j.1351-0754.2003.0556.X 